\title{
PENGEMBANGAN MODEL GAME THEORY PADA SKEMA PERSEDIAAN PENYANGGA UNTUK MENJAMIN KETERSEDIAAN DAN KESTABILAN HARGA KOMODITAS GULA PASIR
}

\author{
Mahesa Jenar"), Wahyudi Sutopo *), Yuniaristanto*) \\ Jurusan Teknik Industri Fakultas Teknik Universitas Sebelas Maret \\ Jalan Ir. Sutami 36 A, Surakarta 57126, Indonesia
}

\begin{abstract}
Abstrak
Bahan pokok yang setiap hari dikonsumsi masyarakat Indonesia antara lain beras, gula pasir, dan minyak goreng. Bahan pokok tersebut merupakan hasil dari sektor pertanian atau komoditas pertanian. Komoditas pokok tersebut dikonsumsi oleh masyarakat Indonesia sepanjang tahun dalam jumlah yang sangat besar. Karena komoditas pokok diperlukan sepanjang tahun, ketersediaan terhadap komoditas pokok merupakan hal yang sangat penting bagi masyarakat Indonesia. Dalam rangka menjaga ketahanan pangan, salah satu cara untuk mengatasi permasalahan tersebut dengan menyediakan persediaan penyangga sebagai instrumen untuk mengendalikan keseimbangan pasokan dan permintaan pasar. Baik produsen, pedagang, dan konsumen menggunakan strategi masing-masing yang bersesuaian dengan kepentingan tersebut. Untuk itu diperlukan suatu pendekatan matematis yang dapat menganalisa proses pengambilan keputusan yang melibatkan dua atau lebih kepentingan. Dalam penelitian ini akan digunakan game theory untuk menganalisa pengambilan keputusan dari kepentingan yang terkait. Hasilnya menunjukkan bahwa model game theory dapat menggambarkan hubungan transaksi antara produsen dan konsumen dalam skema persediaan penyangga. Selain itu, game theory dapat menggambarkan beberapa kondisi dalam skema persediaan penyangga melalui strategi yang dikembangkan.
\end{abstract}

Kata kunci : game theory; komoditas pokok; ketersediaan dan kestabilan harga; persediaan penyangga

\begin{abstract}
Indonesian society consumpts some staple commodities such as rice, sugar, and cooking oil. Staple commodities are from agricultural commodities. Staple commodities consumed by the people of Indonesia during the year in a very large number. Because the staple commodities required throughout the year, the availability of the staple commodities is very important for the people of Indonesia. Food security can be ensured by providing a buffer stock as an instrument for controlling the balance of supply and demand. Both producers, traders, and consumers are using their each strategy that corresponding to these interests. It required a mathematical approach that can analyze the decision-making process that involves two or more interests. In this study game theory will be used to analyze the decisions of relevant interests. The result shows that the model of game theory can describe the relationship between producer and consumer transactions in the buffer stock scheme. Moreover, game theory can describe some of the conditions in the buffer stock scheme through a strategy developed.
\end{abstract}

Keywords : game theory; staple commodities; availability and price stability; buffer stock

\section{Pendahuluan}

Masyarakat Indonesia tidak terlepas dari kebutuhan bahan pokok. Bahan pokok yang setiap hari dikonsumsi masyarakat Indonesia antara lain beras, gula pasir, dan minyak goreng. Bahan pokok tersebut merupakan hasil dari sektor pertanian atau komoditas

\footnotetext{
${ }^{*}$ Penulis Korespondensi. email: jenarmahesa025@gmail.com, wahyudisutopo@gmail.com, yuniaristanto@gmail.com
}

pertanian. Komoditas pokok tersebut dikonsumsi oleh masyarakat Indonesia sepanjang tahun dalam jumlah yang sangat besar. Karena komoditas pokok diperlukan sepanjang tahun, ketersediaan terhadap komoditas pokok merupakan hal yang sangat penting bagi masyarakat Indonesia. Namun yang sering terjadi adalah kelangkaan pasokan terhadap kebutuhan komoditas pokok dan disparitas harga yang mencolok antar wilayah di Indonesia. Hal tersebut terjadi karena ketidakseimbangan antara permintaan terhadap komoditas dan penawaran yang dapat dipenuhi produsen komoditas pokok. Oleh sebab itu, 

mengakibatkan harga keseimbangan pasar (equilibrium price) yang semula $\mathrm{P}_{0}$ naik menjadi $\mathrm{P}_{1}$. Sedangkan jumlah barang (quantity) yang pada awalnya $\mathrm{Q}_{0}$ turun menjadi $Q_{1}$.

\section{Game Theory}

Teori permainan (game theory) adalah suatu pendekatan matematis untuk merumuskan situasi persaingan dan konflik antara berbagai kepentingan. Teori ini dikembangkan untuk menganalisa proses pengambilan keputusan dari situasi-situasi persaingan yang berbeda-beda dan melibatkan dua atau lebih kepentingan. Misal, para manajer pemasaran bersaing dalam memperebutkan bagian pasar, para pimpinan serikat dan manajemen yang terlibat dalam penawaran kolektif, para jenderal tentara yang ditugaskan dalam perencanaan dan pelaksanaan perang, dan para pemain catur, yang semuanya terlibat dalam usaha untuk memenangkan permainan.

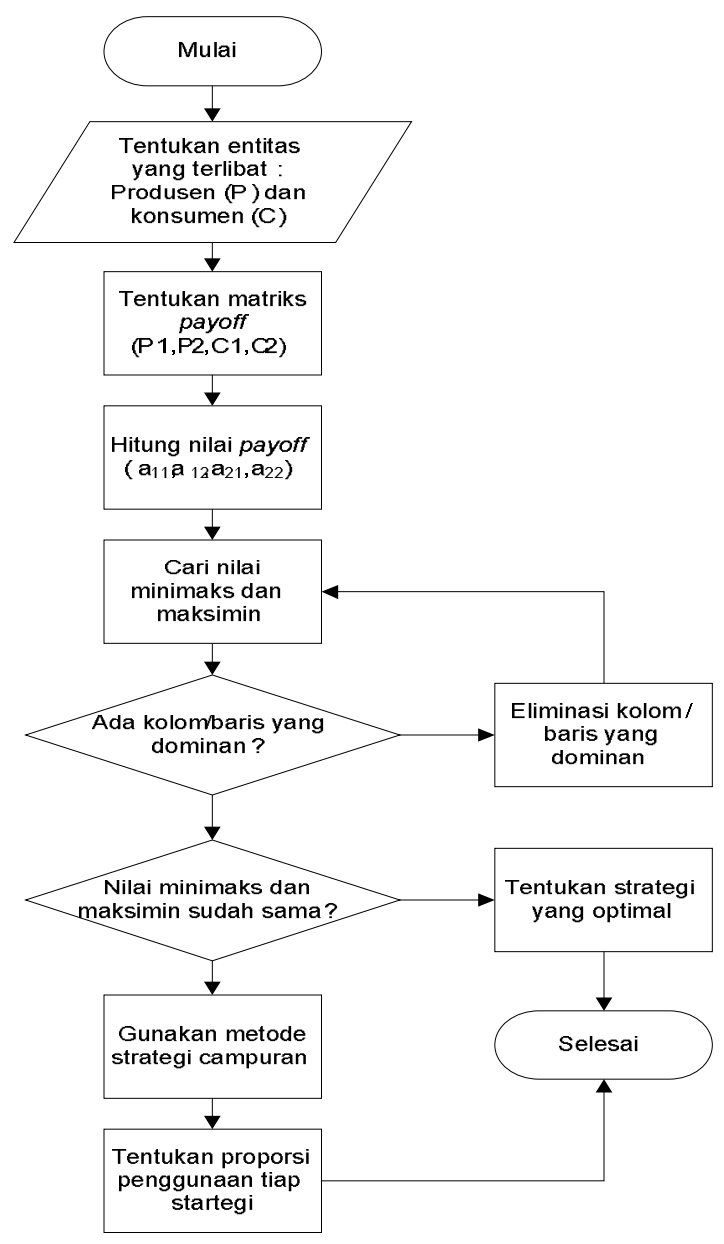

Gambar 3. Flowchart Game Theory

Teori permainan mula-mula dikemukakan oleh seorang ahli matematika Perancis yang bernama Emile Borel pada tahun 1921. Kemudian John Von Neumann dan Oskar Morgenstern mengembangkan lebih lanjut sebagai alat untuk merumuskan perilaku ekonomi yang Jurnal Teknik Industri, Vol. X, No. 2, Mei 2015 bersaing. Aplikasi-aplikasi nyata yang paling sukses dari teori permainan banyak ditemukan dalam bidang militer. Tetapi dengan berkembangnya dunia usaha (bisnis) yang semakin bersaing dan terbatasnya sumber daya serta saling kebergantungan sosial, ekonomi dan ekologi yang semakin besar, akan meningkatkan pentingnya aplikasi-aplikasi bisnis teori permainan. Langkah-langkah Game Theory disajikan pada Gambar 3.

\section{Metode dan Pemodelan}

Model matematis yang digunakan sebagai acuan adalah model Sutopo dkk. (2011). Model Sutopo dkk. (2011) merupakan model persediaan penyangga untuk menjamin ketersediaan pasokan dan kestabilan harga komoditas gula pasir.

Asumsi yang digunakan dalam penelitian ini adalah horizon perencanaan dibagi menjadi dua belas periode yang dikelompokkan menjadi empat kelompok. Empat kelompok tersebut antara lain: awal musim panen dari periode pertama sampai periode ketiga, akhir musim panen dari periode keempat sampai periode keenam, awal musim tanam dari periode ketujuh sampai periode kesembilan, dan akhir musim tanam dari periode kesepuluh sampai periode kedua belas. Asumsi kondisi pasar yang digunakan ditampilkan pada Tabel 1.

Tabel 1. Asumsi Kondisi Pasar

\begin{tabular}{ccccc}
\hline & \multicolumn{4}{c}{ Periode } \\
& $\mathrm{t}_{1}-\mathrm{t}_{3}$ & $\mathrm{t}_{4}-\mathrm{t}_{6}$ & $\mathrm{t}_{7}-\mathrm{t}_{9}$ & $\mathrm{t}_{10}-\mathrm{t}_{12}$ \\
\hline $\begin{array}{c}\text { Horizon } \\
\text { rencana }\end{array}$ & $\begin{array}{c}\text { Awal } \\
\text { musim } \\
\text { panen }\end{array}$ & $\begin{array}{c}\text { Akhir } \\
\text { musim } \\
\text { panen }\end{array}$ & $\begin{array}{c}\text { Awal } \\
\text { musim } \\
\text { tanam }\end{array}$ & $\begin{array}{c}\text { Akhir } \\
\text { musim } \\
\text { tanam }\end{array}$ \\
Produksi & Normal & Berlimpah & $\begin{array}{c}\text { Tidak } \\
\text { ada }\end{array}$ & $\begin{array}{c}\text { Tidak } \\
\text { ada }\end{array}$ \\
$\begin{array}{c}\text { Konsumsi } \\
\text { Ketersedia } \\
\text { an }\end{array}$ & Stabil & Stabil & Stabil & Stabil \\
& Cukup & Berlimpah & Cukup & Kurang \\
\hline \multicolumn{5}{c}{ Sumber: Sutopo dkk. (2011) }
\end{tabular}

Strategi yang diterapkan untuk produsen dan konsumen disajikan pada tabel berikut.

Tabel 2. Strategi Produsen-Konsumen

\begin{tabular}{cccc}
\hline & & & $\begin{array}{c}\text { Produsen menjual } \\
\text { gula pasir ke } \\
\text { konsumen dan } \\
\text { BLUPP }\end{array}$ \\
\cline { 3 - 4 } Strategi & Produsen & P1 & $\begin{array}{c}\text { Produsen hanya } \\
\text { menjual gula pasir } \\
\text { ke BLUPP }\end{array}$ \\
\cline { 2 - 4 } & & P1 & $\begin{array}{c}\text { Konsumen membeli } \\
\text { langsung dari } \\
\text { produsen }\end{array}$ \\
\cline { 2 - 4 } & Konsumen & C2 & $\begin{array}{c}\text { Konsumen membeli } \\
\text { melalui BLUPP }\end{array}$ \\
\cline { 2 - 3 } & & &
\end{tabular}


Sedangkan matriks payoff untuk produsen dan konsumen ada pada Tabel 3.

Tabel 3. Matriks Payoff Produsen-Konsumen

\begin{tabular}{ccc}
\hline \multirow{2}{*}{ Produsen } & C1 & Konsumen \\
& $\mathrm{a}_{11}$ & $\mathrm{C} 2$ \\
\hline $\mathrm{P} 1$ & $\mathrm{a}_{12}$ \\
$\mathrm{P} 2$ & $\mathrm{a}_{21}$ & $\mathrm{a}_{22}$ \\
\hline
\end{tabular}

Pada kondisi $\mathrm{a}_{11}$ strategi yang diterapkan oleh produsen adalah P1 (produsen menjual gula pasir ke konsumen dan BLUPP) dan strategi yang diterapkan konsumen adalah $\mathrm{C} 1$ (konsumen membeli langsung dari produsen). Pada kondisi $\mathrm{a}_{12}$ strategi yang diterapkan oleh produsen adalah P1 (produsen menjual gula pasir ke konsumen dan BLUPP) dan strategi yang diterapkan konsumen adalah C2 (konsumen membeli melalui BLUPP). Pada kondisi ini konsumen membeli gula pasir langsung dari BLUPP. Pada kondisi $\mathrm{a}_{21}$ strategi yang diterapkan oleh produsen adalah P2 (produsen hanya menjual gula pasir ke BLUPP) dan strategi yang diterapkan konsumen adalah $\mathrm{C} 1$ (konsumen membeli langsung dari produsen). Pada kondisi $\mathrm{a}_{22}$ strategi yang diterapkan oleh produsen adalah P2 (produsen hanya menjual gula pasir ke BLUPP) dan strategi yang diterapkan konsumen adalah C2 (konsumen membeli melalui BLUPP).

\section{Hasil dan Pembahasan}

Notasi yang digunakan dalam pengembangan model game theory sebagai berikut.

$\mathrm{TC}^{\mathrm{C}}=$ total biaya konsumen

$\mathrm{p}_{\mathrm{t}}^{\mathrm{p}}=$ harga pasar di level produsen pada periode $\mathrm{t}$

$\mathrm{p}_{\mathrm{t}}^{\mathrm{s}}=$ harga pasar di level konsumen pada periode $\mathrm{t}$

$\mathrm{P}^{\max }=$ harga jual batas atas di level konsumen

$\mathrm{c}_{\mathrm{d}} \quad=$ tarif ongkos distribusi pedagang per unit

$\mathrm{b}=$ konstanta kurva logaritma pada fungsi rasio harga

$\mathrm{c} \quad=$ konstanta fungsi harga pasar di level produsen

$\mathrm{d}=$ konstanta fungsi harga pasar di level konsumen

$\mathrm{CI}_{\mathrm{C}}=$ indikator krisis harga pasar di level konsumen

$\mathrm{p}^{\mathrm{PO}^{\mathrm{O}}}=$ harga pasar di level produsen per unit pada pasar bebas

$\mathrm{t}_{\mathrm{j}}=$ periode dimulainya program stabilisasi harga

$\mathrm{T}=$ periode waktu

$\mathrm{q}_{\mathrm{t}}^{\mathrm{d}}=$ jumlah permintaan konsumen pada periode $\mathrm{t}$

$\mathrm{q}_{\mathrm{t}}^{2}=$ jumlah pasokan ke pasar pada periode $\mathrm{t}$

$Q_{t}^{\mathrm{C}}=$ jumlah komoditas pokok yang dijual BLUPP pada periode $t$

$\mathrm{P} 1=$ strategi produsen yang pertama

$\mathrm{P} 2=$ strategi produsen yang kedua

$\mathrm{C} 1=$ strategi konsumen yang pertama

$\mathrm{C} 2=$ strategi konsumen yang kedua

$\mathrm{a}_{11}=$ hasil dari penerapan strategi $\mathrm{P} 1 \mathrm{C} 1$

$\mathrm{a}_{12}=$ hasil dari penerapan strategi P1C2

$\mathrm{a}_{21}=$ hasil dari penerapan strategi $\mathrm{P} 2 \mathrm{C} 1$

Jurnal Teknik Industri, Vol. X, No. 2, Mei 2015 $\mathrm{a}_{22}=$ hasil dari penerapan strategi $\mathrm{P} 2 \mathrm{C} 2$

Formulasi model yang digunakan untuk model game theory mengacu pada model Sutopo dkk. (2011) dan disajikan pada persamaan berikut.

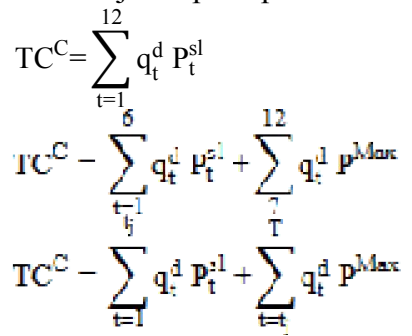

Batasan-batasan yang ada dalam model tersebut :

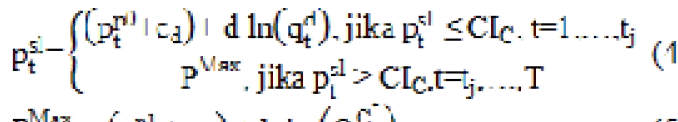

$\mathrm{P}^{\mathrm{Max}}-\left(\mathrm{p}_{\mathrm{p}}^{\mathrm{pl}}+\mathrm{c}_{\mathrm{d}}\right)-\mathrm{b} \ln \left(\mathrm{Q}_{\mathrm{t}}^{\mathrm{C}}\right)$

$\mathrm{p}_{\mathrm{t}}^{\mathrm{F}^{\mathrm{l}}}=\mathrm{p}_{0}^{\mathrm{r}^{\mathrm{C}}}-c \ln \left(\mathrm{q}_{\mathrm{i}}^{\mathrm{s}}\right)$

$\mathrm{t}_{\mathrm{j}}=\{7, \ldots, 12\}, \mathrm{T}=12, \mathrm{P}^{\mathrm{Max}} \geq 0$

Untuk kondisi $\mathrm{a}_{11}$ dan $\mathrm{a}_{21}$ menggunakan formula (1). Sedangkan untuk kondisi $\mathrm{a}_{12}$ menggunakan formula (2). Pada kondisi $\mathrm{a}_{22}$ menggunakan formulasi (3).

Data permintaan-penawaran gula pasir dan parameter yang digunakan pada penelitian ini adalah data hipotetik yang mempertimbangkan data Sutopo dkk. (2011).

Tabel 4. Data Pasokan dan Permintaan Tahun 201x

\begin{tabular}{ccccccc}
\hline Periode & $\mathrm{t}_{1}$ & $\mathrm{t}_{2}$ & $\mathrm{t}_{3}$ & $\mathrm{t}_{4}$ & $\mathrm{t}_{5}$ & $\mathrm{t}_{6}$ \\
\hline $\mathrm{q}^{\mathrm{s}}$ (ribu ton) & 480 & 960 & 960 & 1100 & 1260 & 940 \\
$\mathrm{q}^{\mathrm{d}}$ (ribu ton) & 400 & 460 & 460 & 520 & 560 & 560 \\
\hline Periode & $\mathrm{t}_{7}$ & $\mathrm{t}_{8}$ & $\mathrm{t}_{9}$ & $\mathrm{t}_{10}$ & $\mathrm{t}_{11}$ & $\mathrm{t}_{12}$ \\
\hline $\mathrm{q}^{\mathrm{s}}$ (ribu ton) & 0 & 0 & 0 & 0 & 0 & 0 \\
$\mathrm{q}^{\mathrm{d}}$ (ribu ton) & 520 & 460 & 480 & 480 & 480 & 420 \\
\hline
\end{tabular}

Tabel 5. Data Konstanta dan Parameter Biaya Tahun 201x dalam satuan juta rupiah per ribu ton komoditas pokok

\begin{tabular}{cccccc}
\hline $\mathrm{c}_{\mathrm{d}}$ & $\mathrm{p}^{\mathrm{p} 0}$ & $\mathrm{CI}_{\mathrm{C}}$ & $\mathrm{b}$ & $\mathrm{c}$ & $\mathrm{d}$ \\
\hline 800 & 14000 & 20000 & 0,018 & 6 & 18 \\
\hline
\end{tabular}

Hasil dari model game theory merupakan nilai $\mathrm{a}_{11}, \mathrm{a}_{12}$, $\mathrm{a}_{21}, \mathrm{a}_{22}$ yang disajikan dalam bentuk matriks payoffs. Hasil game theory untuk produsen-konsumen disajikan pada tabel berikut. 
Tabel 6. Hasil Game Theory Produsen-Konsumen dalam satuan juta rupiah

\begin{tabular}{ccc}
\hline \multirow{2}{*}{ Produsen } & \multicolumn{2}{c}{ Konsumen } \\
& $\mathrm{C} 1$ & $\mathrm{C} 2$ \\
\hline $\mathrm{P} 1$ & $\mathrm{Rp} 86.485 .770$ & $\mathrm{Rp} 86.049 .452$ \\
$\mathrm{P} 2$ & $\mathrm{Rp} \mathrm{0}$ & $\mathrm{Rp} \mathrm{86.422.161}$ \\
\hline
\end{tabular}

Solusi dari model game theory menggunakan kriteria maksimin dan minimaks. Pemain baris (maximizing player) mengidentifikasikan strategi optimalnya melalui aplikasi kriteria maksimin (maximin). Sedangkan pemain kolom (minimizing player) menggunakan kriteria minimaks (minimax) untuk mengidentifikasikan strategi optimalnya. Dalam hal ini nilai yang dicapai harus merupakan maksimum dari minimaks baris dan minimum dari maksimin kolom sekaligus. Solusi dari model akan memberikan total manfaat bagi konsumen yang optimal seperti pada tabel berikut.

Tabel 7. Kriteria Maksimin dan Minimaks ProdusenKonsumen dalam satuan juta rupiah

\begin{tabular}{cccc}
\hline \multirow{2}{*}{ Produsen } & $\mathrm{C} 1$ & Konsumen & Minimal Value \\
\hline $\mathrm{P} 1$ & $\mathrm{Rp} 86.485 .770$ & $\mathrm{Rp} \mathrm{86.049.452}$ & $\mathrm{Rp} \mathrm{86.049.452}$ \\
$\mathrm{P} 2$ & $\mathrm{Rp} \mathrm{0}$ & $\mathrm{Rp} \mathrm{86.422.161}$ & $\mathrm{Rp} \mathrm{86.422.161}$ \\
$\begin{array}{c}\text { Maximal } \\
\text { value }\end{array}$ & $\mathrm{Rp} \mathrm{86.485.770}$ & $\mathrm{Rp} \mathrm{86.422.161}$ & \\
\hline
\end{tabular}

Dari Tabel 7 terlihat bahwa nilai minimum dari maksimin kolom yaitu sebesar Rp 86.422.161 juta dan nilai maksimum dari minimaks yaitu $\mathrm{Rp} 86.422 .161$ juta. Hal ini membuat solusi dari game theory produsen-konsumen terdapat titik pelana yaitu sebesar Rp 86.422.161 juta.

Model game theory memberikan beberapa strategi yang dapat dipilih produsen atau konsumen. Strategi tersebut masing-masing memberikan nilai payoff yang berbeda-beda. Solusi dari model game theory menunjukkan strategi mana yang dapat dipilih oleh masing-masing entitas yang terlibat untuk mendapatkan nilai payoff yang optimal. Dari kriteria maksimin dan minimaks didapatkan nilai TC sebesar Rp 86.422.161 juta. Dengan demikian strategi optimal yang dipilih oleh produsen adalah strategi P2 dan yang dipilih konsumen adalah strategi C2. Dimana produsen hanya menjual gula pasir ke BLUPP dan konsumen membeli gula pasir melalui BLUPP.

Pada strategi P2C2 konsumen hanya akan membeli gula pasir dari BLUPP. Dari periode $\mathrm{t}=1$ sampai $\mathrm{t}=11$ jumlah pasokan gula pasir yang diperoleh BLUPP dari produsen masih mencukupi permintaan konsumen. Pada periode ini konsumen membeli gula pasir dengan harga pasar di level konsumen. Sedangkan pada periode $t=12$ pasokan gula pasir sudah tidak mencukupi kebutuhan konsumen. Pada saat ini BLUPP memberikan harga jual batas atas di level konsumen agar konsumen terhindar dari harga yang terlalu tinggi.

Dengan menjual hasil produksi gula pasir ke BLUPP produsen terhindar dari harga jual yang murah ketika musim panen. Pasokan gula pasir yang melimpah saat musim panen membuat harga jual rendah. Konsumen yang membeli dari BLUPP juga akan terhindar kelangkaan dan lonjakan harga ketika musim tanam. Kelangkaan gula pasir disebabkan oleh oknum-oknum yang sengaja menimbun gula pasir untuk mendapatkan harga jual gula pasir yang tinggi. Dengan adanya persediaan penyangga gula pasir, BLUPP dapat mengontrol penjualan komoditas gula pasir dan memberikan harga yang layak bagi produsen konsumen.

Game theory dapat digunakan untuk menggambarkan hubungan transaksi antara produsen dan konsumen. Selain itu, game theory juga dapat memberikan gambaran yang lebih luas tentang hubungan produsen dan konsumen melalui strategistrategi yang dikembangkan melalui satu kali proses. Jika entitas yang dilibatkan lebih banyak dan strategi yang dikembangkan juga lebih luas maka game theory dapat menggambarkan berbagai macam kemungkinan yang terjadi pada setiap entitas.

\section{Kesimpulan}

Model game theory dapat menggambarkan beberapa kondisi yang diuraikan dalam strategi-strategi pada model produsen-konsumen. Model game theory dapat menunjukkan strategi yang dapat dikembangkan dalam skema persediaan penyangga dan kestabilan harga komoditas pokok.

Pada penelitian selanjutnya sebaiknya dikembangkan strategi yang lebih menarik untuk model game theory sehingga bisa didapatkan solusi optimal yang lebih baik. Penelitian selanjutnya sebaiknya dilibatkan entitas yang lain sehingga dapat menggambarkan transaksi secara keseluruhan. Penggunaan Lingo untuk mencari solusi optimal dapat digunakan untuk meningkatkan tingkat akurasi.

\section{Daftar Pustaka}

Andrews, R., Munro, R., dan Field, M. 2007. Building a Warehouse Receipts Program that Works for All Stakeholders, USAID, http://www.businessgrowthinitiative.org. Diunduh pada tanggal 9 Desember 2012

Ashari. 2011. Potensi dan Kendala Sistem Resi Gudang (SRG) untuk Mendukung Pembiayaan Usaha Pertanian di Indonesia. Forum Penelitian Agro Ekonomi, 29(2), 129-143.

Ashari. 2010. Prospek Sistem Resi Gudang (SRG) sebagai Alternatif Pembiayaan Sektor Pertanian. ICASEPS Working Paper, 102, 1-22.

Ashari. 2007. Resi Gudang: Alternatif Model Pemasaran Komoditas Pertanian. Warta Penelitian dan Pengembangan Pertanian, 29(4), 7-8. 
Athanasioua, G., Karafyllisb, I., and Kotsiosa, S. (2008). "Price Stabilization Using Buffer Stocks". Journal of Economic Dynamics and Control, Vol 32, pp. 1212-1235.

Baye, M.R. 2006. Managerial Economics and Business Strategy, 5th edition. McGraw-Hill, USA.

Dorosh, P.A., Dradri, S., dan Haggblade, S. 2009. Regional Trade, Government Policy and Food Security, Recent Evidence from Zambia. Food Policy, 34, 350-366.

Forssell, S. 2009. Rice Price Policy in Thailand: Policy Making and Recent Developments. Working Paper, Department of Economics at the University of Lund Sweden.

Höllinger, F., Rutten, L., dan Kiriakov, K. 2009. The Use of Warehouse Receipt Finance in Agriculture in Transition Countries, FAO of the United Nations, http://www.fao.org/tc/tci. Diunduh pada tanggal 9 Desember 2012.

Isma'il, N.M. 2001. Peningkatan Industri Daya Saing Gula Nasional sebagai Langkah Menuju Persaingan Bebas. Institute for Science and Technology Studies Journal, II, 3-14.

Jamhari. 2004. Rice Market Liberalization And Price Stability in Indonesia. Tohoku Journal of Agricultural Research, 54(3-4), 23-36.

Salvatore, D. 2004. Managerial Economics in a Global Economy, 5th Edition. South-Western.
Subagyo, Pangestu. 1990. Dasar-Dasar Operations Research. Yogyakarta : Penerbit UGM.

Sutopo, W., Nur Bahagia, S., Cakravastia, A., dan Arisamadhi, TMA. 2009a. A Dynamic Buffer Stocks Model for Stabilizing Price of Staple Food with Volatility Target. International Journal of Logistics and Transport, 3(2), 149160.

Sutopo W., Nur Bahagia S., Cakravastia A. dan Arisamadhi, TMA. 2009b. A Buffer Stocks Model for Stabilizing Price with Considering The Expectation Stakeholders in The Staplefood Distribution System. Proceedings the 5th IILS Conf., 101.1-101.10.

Sutopo, W., Nur Bahagia, S., Cakravastia, A. Dan Arisamadhi, TMA. 2009c. A Buffer Stocks Model for Stabilizing Price in Duopoly-Like Market. Proceedings of the 2nd Asia Pacific Conf. on Manufacturing System Conference, IV.9-IV.16.

Sutopo, W., Nur Bahagia, S., Cakravastia, A. dan Arisamadhi, TMA. 2008. A Buffer Stocks Model to Stabilizing Price of Commodity under Limited Time of Supply and Continuous Consumption. Proceedings of the 9th APIEMS, 321-329. 